Aquat. Liting Resour., 1988, I, 215-222

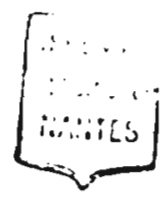

\title{
Sea bass (Dicentrarchus labrax) reproduction in captivity : gametogenesis and spawning
}

\author{
f Nicole Devauchelle ${ }^{(1)}$ and Denis Coves ${ }^{(2)}$ \\ (1) IFRE.1IER, Centre de Brest, B.P. $n^{\circ} 70,29263$ Plouzant (France). \\ (2) IFRE.MER, chemin de Maguelone, 34250 Palaras-les-Flots (France).
}

Reccived July 18,1988 , accepted October 24, 1988.

Abstract This paper describes the large-scale production of eggs and larvae of sea bass (Dicentrarchus labrax)

Devauchclle N., D. Coves, Aquat. Liting Resour., 1988, 1, 215-222. and shows how spawning can be planned to produce viable eggs throughout the year by manipulation of photoperiod and temperature. The rearing temperature was $9.5-22^{\circ} \mathrm{C}$ during spawning and $9-24^{\circ} \mathrm{C}$ during the gametogenesis. The photoperiodic cycles tested were normal (i.e. the photoperiodic cycle observed at Palavas-les-Flots, mediterranean coast, France, 1984/1987) advanced by 3 to 5 months and delayed by 2 months.

Keywords : Sea I3ass, Dicentrarchus labräx, spawning, reproduction, aquaculture.

La reproduction du bar (Dicentrarchus labrax) en capticité : gamétogenèse et ponte.

Résumé

La production à grande échelle d'œufs ct larves de bar (Dicentrarchus labrax) peut être planifièe à quelque moment de l'année que ce soit, en manipulant la photopériode et la tempéralure. Pour la ponte, la température doit être maintenue entre 9 et $22^{\circ} \mathrm{C}$. Elle doit ètre inférieure à $26^{\circ} \mathrm{C}$ pendant la gamétogenèse. Trois cycles photopériodiques ont été testés: un cycle avancé de 3 à 5 mois, un cycle retardé de 2 mois, et le cycle normal observé dans la région de Palavas-les-Flots, France, 1984/1987.

Mots-clés : Bar, Dicentrarchus labrax, ponte, ieproduction, aquaculture.

\section{INTRODUCTION}

The rearing of marine fish requires a reliable supply of eggs and normal yolksac larvac. Gametes from fish that have matured in the wild and been caught when ripe are not a solution for thrce main rcasons: the annual productivity in the sea is variable from year to year; even with high productivity, sperm and oocytes of good quality are difficult to obtain; and the production of gametes in the wild is seasonal.

The control of spawning in captivity, on the other hand allows a better monitoring of the quantity and quality of eggs collected during or outside the normal spawning periods. Early results from freshwater salmonids were obtained by stripping and artificial fertilization (Huet, 1970). The first tests on marine fish were run later, at the end of the last century and especially during the sixties and seventies. These followed different strategies, depending on the species and the geographical area. In summary, Matfish such as plaice (Pleuronectes platessa), turbot (Scophthalmus maximus) and sole (Solea solea) traditionally spawned and fertilized their eggs naturally in tanks of running sea water (Shelbourne, 1968; Devauchelle et al., 1987, 1988). However, mullet (Mugil cephalus) spawned only after hormonal injections (Kuo et al., 1973), while cggs of sea bream (Sparus aurata) and sea 
bass (Dicentrarchus labrax) were obtained naturally (Boulineau, 1969; Girin, 1979; Devauchelle, 1984) or with hormonal help, most often HCG (IIuman chorionic gonadotropin) (Barnabé, 1976a, 1976b; Bedier, 1979; Zanuy et Carillo, 1984) and LHRH (Luteinizing hormone releasing hormone) injections (Zohar et al., 1984; Barnabé et Barnabé-Quet, 1985; Suquet, 1986), sometimes followed by handstripping. Production of eggs outside the normal spawning season was obtained under artificial thermal and photoperiodic cycles (Girin et Devauchelle, 1978; Barnabé et Paris, 1984; Devauchelle, 1984; Coves, 1985; Zanuy et al., 1986) which have a major effect on gametogenesis under the temperature regimes found at this latitude (43.31 N).

Several works describe and compare the results of such experiments during the last 15 to 20 years (Barnabé, 1986; Devauchelle, 1986), all conclude that more fundamental research needs to be done. It is also necessary for commercial hatcheries to transfer to a large scale the techniques developed in laboratories.

Experiments with this latter aim have now been carried out on the gametogenesis and spawning of sea bass. These were successfull in readily producing large number of eggs and yolksac larvae at any season. The results are presented here.

\section{MATERIAL AND METHODS}

\section{Stock management}

This section describes the conditions used at the IFREMER Laboratory during the years 1984 to 1987. This laboratory is situated on the mediterranean coast of France (at $43.31 \mathrm{~N}$ ). The broodstock consisted of equal numbers of wild fish and fish reared in hatcheries. Fish from the wild were chosen without abnormalities, and hatchery reared fish were selected on the basis of highest growth rate. Each group of spawners contained several weight classes: five classes of females ranging from 1 to $4 \mathrm{~kg}$ and four classes of males weighing 0.7 to $2.5 \mathrm{~kg}$. At the end of each spawning season, the highest wcight class of fish was replaced by a young class to give an annual renewal of an average of $20 \%$ of the whole group. The sex ratio was 1 male to 2 or 3 females, i.e. female weight represented at least $75 \%$ of total biomass. In each group, stocking density varied from 4 to $13 \mathrm{~kg} / \mathrm{m}^{3}$ without cffect on fecundity or egg fertilization and hatching percentages.

Fish were transported to the experimental facilitics in small tanks $\left(0.5\right.$ to $\left.1 \mathrm{~m}^{3}\right)$ at variable densities (10 to $200 \mathrm{~kg} / \mathrm{m}^{3}$ ) depending on transport duration (maximum 6 hours) and water temperature $\left(9.25^{\circ} \mathrm{C}\right.$ ). $\Lambda$ naesthesic is recommended only for excited fish. At their arrival at the station, fish were stocked in a tank for 1 to 6 months. On arrival, the fish underwent sanitary treatment at ambiant temperatures $\left(9-25^{\circ} \mathrm{C}\right)$. On the first day, fish were placed in a furazolidone bath $\left(20\right.$ to $\left.30 \mathrm{~g} / \mathrm{m}^{3}\right)$ for 30 minutes. The following day, a second treatment was administered with formalin $\left(350 \mathrm{~g} / \mathrm{m}^{3}\right)$ for 30 minutes. These two treatments were repeated respectively on the third and the fourth day. During the first month of their acclimatization the fish were sexed with special scissors (Devauchelle, 1985).

The maturation tank capacity was $12 \mathrm{~m}^{3}$. Its organization described ( $f i g .1$ ) was based on a completely open seawater circulation system. The flow rate was adjusted to give an average total volume renewal of $10 \%$ per hour for stocking densities ranging from 4 to $6 \mathrm{~kg} / \mathrm{m}^{3}$. In case of higher densities, the flow rate was doubled to keep the dissolved oxygen up to $80 \%$ of saturation. Each tank was aerated. Eggs were collected in a plankton net placed under the outflow. Lighting was provided by fluorescent lights giving a maximum 1500 lux at the surface of the tank.

The fish were fed daily ad libitum (with a diet consisting of 60 to $80 \%$ artificial pellets (Aqualim-7 mm) and $20-40 \%$ trash fish of various species which were fresh or frozen for a maximum 2 months. The tanks were cleaned once a week to once a month, depending on season and stocking density.

\section{Long term retardation of spawning}

Prolongation of the spawning season was caused mainly by photoperiod modifications. Since natural ovulations are only obtained in the thermal range 9$17^{\circ} \mathrm{C}$, the light cycles were adjusted to induce spawning seasons at the period when the natural temperatures reach these levels, most often from October to June. $\Lambda t$ the beginning of the experiments, the fish were all in non-breeding condition. The fish were divided into three groups (table 1). The control group (tank 1) was subjected to natural photoperiodic and thermal cycles ranging from $8 \mathrm{hrs}$. $30 \mathrm{~min}$ to $15 \mathrm{hrs}$. 30 min of light per day and from 9 to $26^{\circ} \mathrm{C}$. Tank 2 was advanced by 3 months in 1985-1986, and by 5 months in 1986-1987. This was obtained by concentrating the decreasing photoperiod into 3 months instead of 6 months in 1985-1986 and 4 months instead of 6 in 1986-1987. Then the period corresponding to the increasing of photoperiod was divided into two phases. The first consisted of photoperiods less than 10 hours of light per day until most females had spawned at least once. Then the photoperiod is quickly increased to 16 hours of light per day. The period between two spawning seasons lasted 12 months. The temperature was that of ambiant scawater. Tank 3 was delayed. In 1984-1985 the decreasing photoperiod is spread over 8 months instead of 6. During the following 12 months the variations of the natural cycle delayed by 2 months were reproduced. In 1986-1987 a supplementary delay of 2 months was tested by spreading the increasing and decreasing photoperiods over 7 months instead of 6 months. The temperature cycles were natural. These changes are shown by figure 4 . 


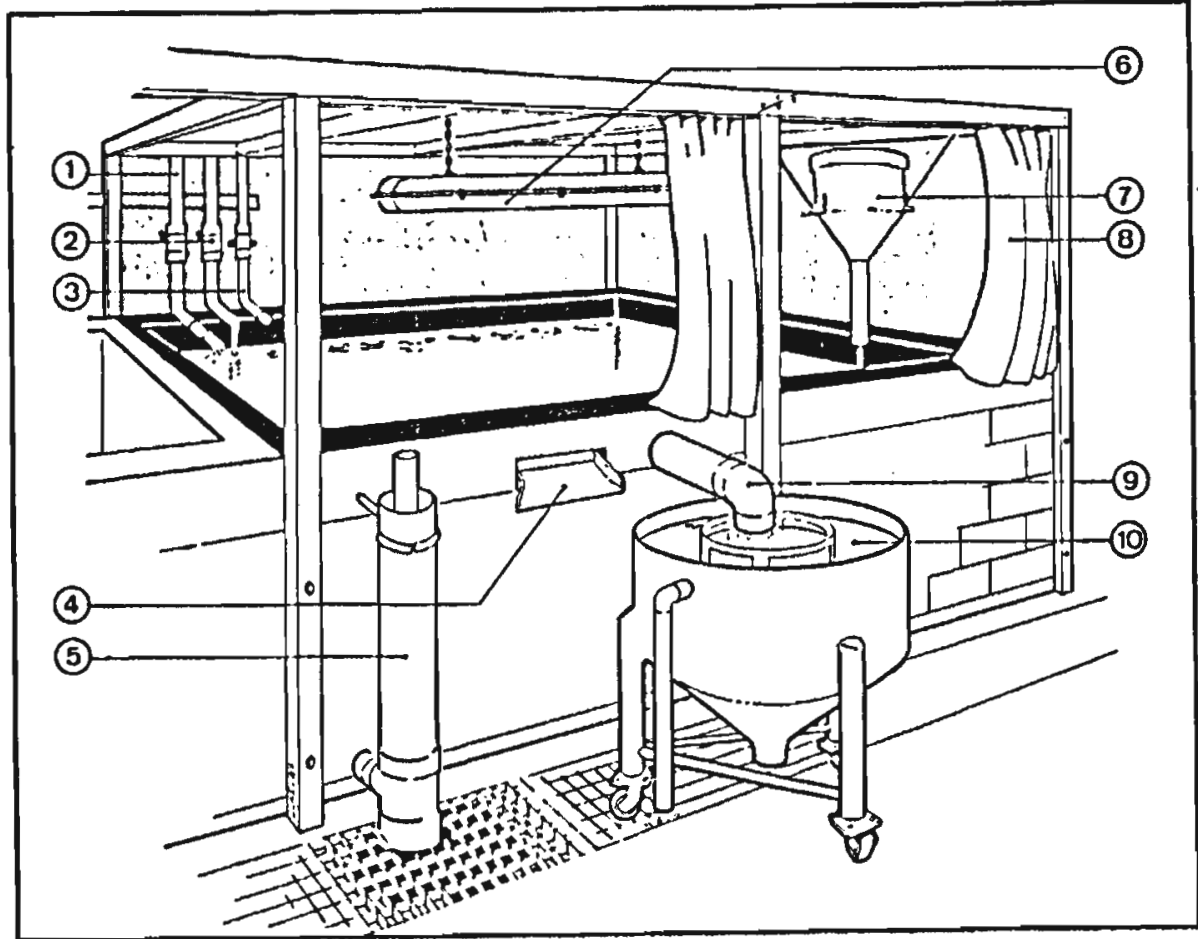

Hgure 1. - Diagram of maturation tank and egg collector. 1: mixed water, 2: aeration, 3: natural water inlet, 4 and 9: surface outflow, 5: bottom outflow, 6: fluorescent tubes to programm lighting, 7: self feeder, 8: opaque curtain, 10: egg collector.

Table 1. - Characteristics of the three groups of spawners.

\begin{tabular}{lcccccccc}
\hline \multicolumn{1}{c}{ Tank } & \multicolumn{1}{c}{1} & \multicolumn{2}{c}{2} & 3 \\
\hline \multicolumn{1}{c}{ Spawning season } & \multicolumn{3}{c}{ Control } & \multicolumn{3}{c}{ Advanced } & \multicolumn{2}{c}{ Delayed } \\
\hline \multicolumn{1}{c}{ Years } & $1984-1985$ & $1985-1986$ & $1986-1987$ & $1985-1986$ & $1986-1987$ & $1984-1985$ & $1985-1986$ & $1986-1987$ \\
\hline Stocking density $\mathbf{~ k g}^{\prime} \mathbf{m}^{3}$ & 3.6 & 10.3 & 13 & 4.7 & 5.2 & 3.4 & 4.8 & 6.1 \\
Number of females & 16 & 30 & 40 & 20 & 20 & 17 & 15 & 21 \\
Number of males & 8 & 19 & 16 & 8 & 8 & 7 & 8 & 8 \\
\hline
\end{tabular}

\section{Spawning collection}

During gametogenesis, biopsies were made with scissors (Devauchelle, 1985) to estimate the growth stages of the oocytes. When oocyte diameters were greater than $650 \mu \mathrm{m}$ the females were injected with $\mathrm{LHRH}_{a}$ (10 to $20 \mu \mathrm{g} / \mathrm{kg}$ fish) and placed in a spawning tank where the eggs were spawned naturally and fertilized naturally at a minimum $13^{\circ} \mathrm{C}, 24$ to 96 hours after injection. Then, each female was subjected to another biopsy. If they still contain oocytes over $650 \mu \mathrm{m}$ diameter, they were again injected with LHRH $_{a}$ as before. $A$ third examination and injection was made if necessary.

The hormonal treatments accelerated the final maturation and ovulation processes. As a consequence, it can be used for short term acceleration of spawning, especially for getting a large quantity of eggs in a short period. When synchronization is not necessary, the fish are left in the stocking tank where they may ovulate and spawn naturally. The fish subjected to hormonal treatments were identified by colored ink injected at the base of the pectoral fin.

Whatever the spawning technique, the eggs of each spawn were automatically collected and concentrated (fig. 1) in a plankton net." Their total number and percentage viability (number of eggs normally segmented/total number of eggs collected) were estimated. Only viable eggs with the highest buoyancy were selected and placed in open water circulation incubators (fig. 2) at densities up to 10000 eggs per liter.

\section{RESULTS}

Mortality of broodstock was observed at two different times, just after fishing and during the acclimatization period. Mortalities occurred in fish, injured 


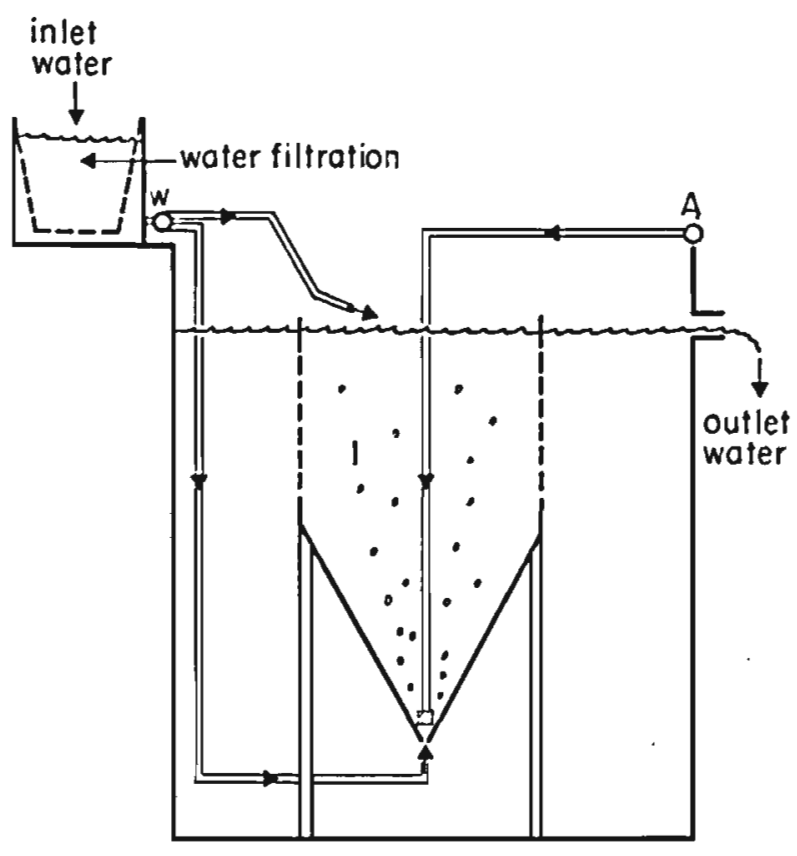

Figure 2. - Diagram of incubators used for large number of eggs at densitics up to 10000 per liter ( $W=$ sea water; $A=$ air; $I=$ incubators).

by successive manipulations, and later in the maturation tank, cspccially when manipulations linked to hormonal treatments were too brutal or too long. In both cases the mortality rate reached $5 \%$ per year.

Mortalities also occurred if fish weighing less than $0.5 \mathrm{~kg}$ were introduced into the maturation tanks, when larger fish sometimes attacked and killed them. In some cases $100 \%$ of such fish were killed in a few days. During the conditioning, the main problems wcre parasites: copepods (Caligidac) were treated by $300 \times 10^{-6}$ formaldehyde once a week until eradicated. Triconemia and metacercaria were suppressed with formaldehyde $(37 \%)$ baths at $200 \times 10^{-6}$; plathelminthes were treated with Mebinzadole 3\% incorporated into the fish food at $4 \mathrm{~g} / \mathrm{kg}$ of diet.

The food intake varied between 1.5 and $11 \%$ (dry food $\mathrm{kg} / \mathrm{kg}$ fish $\times 100$ ) ( fig. 3). The lowest food consumption occurred at the lowest temperatures and at spawning periods, when oocytes measured over $500 \mu \mathrm{m}$. Both factors may explain why in 1986-1987 the fish in the delayed tank ate small quantities over a longer time than the control 2 nd advanced tanks, because the spawning scason began just after the cold period at the start of the increase in temperature.

The spawning periods (fig. 4). - Biopsies during the whole gametogenic cycle showed that ovulation was not well synchronized between fish. However, mean oocyte diameter in a particular tank increased with decreasing photoperiod. The oldest females (2.5$3 \mathrm{~kg}$ ) responded most quickly to stimulation by light. Oocytes longer than $650 \mu \mathrm{m}$ were first observed 4 to
5 months after maximum photoperiod or after the beginning of decreasing photoperiod in tank 1 (control) and 2 (advanced). In tank 3 (delayed season), oocyte diameter increased before the decreasing photoperiod. Females with $650 \mu \mathrm{m}$ diameter oocytes were observed only 1 month after the decrease. Thus the delay was not strictly respected in this treatment: instead of 4 months delay we obtained 2 months.

In tanks 1 and 2, the spawning periods which followed hormonal injections began during the end of the decreasing photoperiod, while natural spawns were collected at increasing photoperiods. In tank 3, natural spawns were obtained cven during the decreasing photoperiod. The maturation processes were observed at temperatures ranging from 9 to $24^{\circ} \mathrm{C}$ and mostly under decreasing photoperiod from 16 to $10-15$ hours of light per day. In any case, viable eggs were obtained between 9.5 and $22^{\circ} \mathrm{C}$ and at photophases ranging from 8 hrs. $30 \mathrm{~min}$ to 15 hours of light per day. When temperatures rose above $17^{\circ} \mathrm{C}$, the use of $\mathrm{LHRH}_{a}$ became necessary to induce spawning. The total fecundity ranged from 146000 to 502300 eggs per kilogram of fish (table 4). Those of groups 1 and 2 were similar while the fecundity in group 3 was somewhat lower. Similar results were obtained for egg viability, while hatching percentages were not clearly different between treatments (table 3).

\section{DISCUSSION}

The methods tested for spreading the spawning season of sea bass gave interesting results: in 19861987 , during 8.5 months, $111.9 \times 10^{6}$ eggs were collected from three tanks controlled mainly by light and containing a total weight of $291 \mathrm{~kg}$ fish. $92.4 \times 10^{6}$ eggs were viable $(82.5 \%$ viability and $66 \%$ gave normal larvae. As observed by several scientists (Billard, 1979; Bromage et al., 1982; Wooton, 1982; Lam, 1983; Duston and Bromage, in press; Bye, 1984), the major control of the initiation of maturation is photoperiod. However, even in our temperate climate, the duration of gametogenesis seems to be closely linked to the tempcrature levels as well as to the spread of thermal variations, as observed for subtropical species (Lam, 1983). In our experiment, use of $\mathrm{LHRH}_{a}$ induced the maturation processes and spontaneous egg release under subnormal temperatures, but it was not cfficient in stimulating any stage of the gametogenesis at any temperature. Control of temperature also appeared necessary in order to fully complete oocyte development. Thus, to delay the spawning season more efficiently than we did, we suggest that temperature levels should be kept high $\left(16<\mathrm{T}^{\circ} \mathrm{C}<22\right)$ or at least to reduce their decrease less rapidly when photoperiod decreased and, as a consequence, initiated gametogenesis. In the case of advanced seasons, the role of temperature does not seem to be so crucial. The delay of 15 days to 1 month 

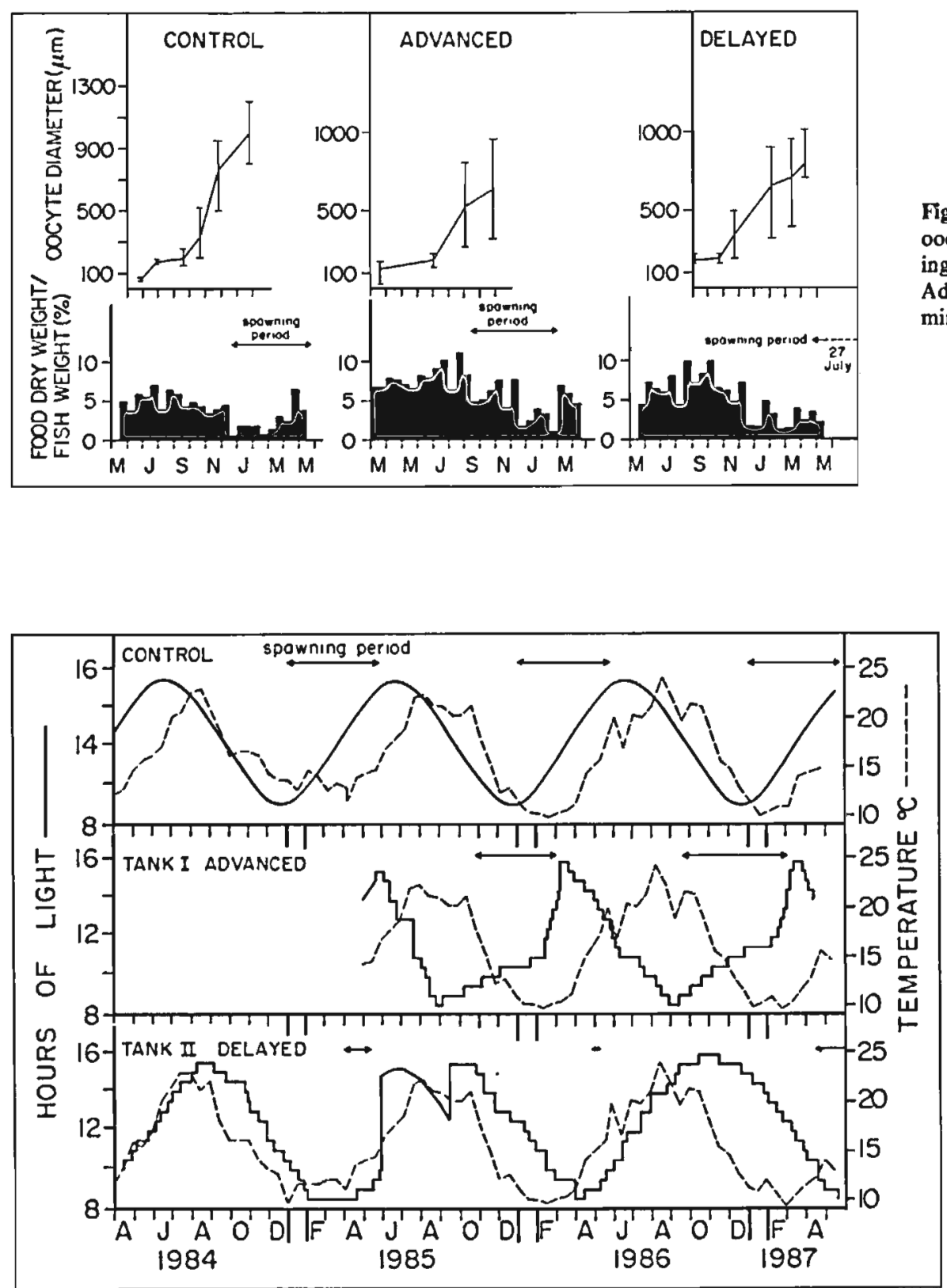

Figure 3. - Changes in food intake and oocyte diameters over the 1986-1987 spawning periods for the three treatments (Control, Advanced and Delayed tanks); vertical bars: min.-max, diameters.
Figure 4. - Variations of temperature and photoperiod in the Control Advanced and Delayed tanks over the period April 1984-A pril 1987.

Table 2. - Light (L) and temperature (T) conditions at the beginning of increasing oocyte diameter, at the $650 \mu \mathrm{m}$ point which is the lower limit for efficient hormonal injections, and when at least $50 \%$ of the oocytes have reach $650 \mu \mathrm{m}$.

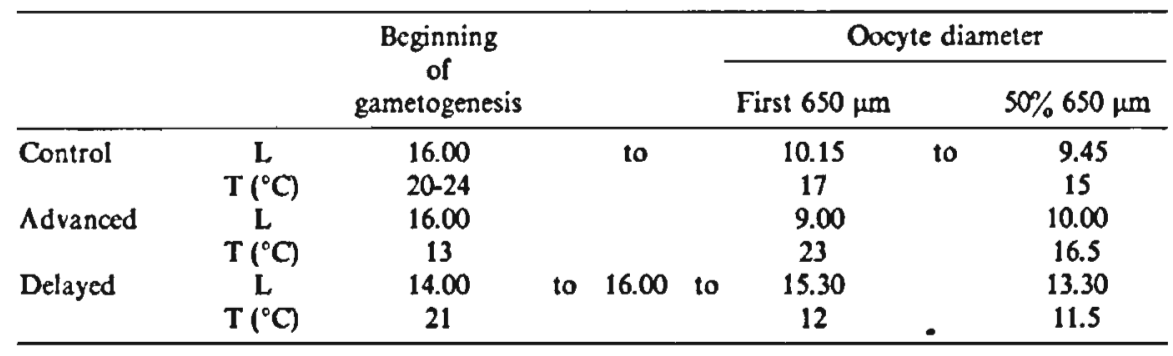

L: Hours. minutes of light per day. 
Table 3. - Spawning seasons and characteristics of eggs collected in the Advanced, Delayed and Control groups.

\begin{tabular}{|c|c|c|c|c|c|c|c|c|}
\hline \multirow[b]{2}{*}{$\begin{array}{c}\text { Year } \\
\text { Spawning period }\end{array}$} & \multicolumn{3}{|c|}{ Control } & \multicolumn{2}{|c|}{ Advanced } & \multicolumn{3}{|c|}{ Delayed } \\
\hline & $\begin{array}{c}\text { 1984-1985 } \\
14 \mathrm{Jan}- \\
1 \mathrm{Apr} .\end{array}$ & $\begin{array}{c}1985-1986 \\
23 \text { Nov.- } \\
28 \text { Apr. }\end{array}$ & $\begin{array}{c}1986-1987 \\
9 \mathrm{Dec} . \\
21 \mathrm{May}\end{array}$ & $\begin{array}{c}\text { 1985-1986 } \\
21 \text { Oct.- } \\
2 \mathrm{Mar} .\end{array}$ & $\begin{array}{c}1986-1987 \\
17 \mathrm{Sepl}- \\
2 \mathrm{Mar} .\end{array}$ & $\begin{array}{c}\text { 1984-1985 } \\
26 \mathrm{Mar} .- \\
16 \mathrm{May}\end{array}$ & $\begin{array}{c}1985-1986 \\
19 \text { Apr.- } \\
8 \mathrm{May}\end{array}$ & $\begin{array}{c}1986-1987 \\
10 \mathrm{Apr} .- \\
27 \mathrm{Jul} .\end{array}$ \\
\hline $\begin{array}{l}\text { Total number of eggs collected } \\
\text { Viability \% } \\
\text { Number of viable eggs per } \mathrm{kg} \\
\text { female }\end{array}$ & $\begin{array}{l}12120000 \\
96 \\
280000\end{array}$ & $\begin{array}{c}27500000 \\
89 \\
284000\end{array}$ & $\begin{array}{c}43700000 \\
85 \\
369000\end{array}$ & $\begin{array}{c}16100000 \\
89 \\
292000\end{array}$ & $\begin{array}{c}20400000 \\
87 \\
437000\end{array}$ & $\begin{array}{c}6486000 \\
86 \\
154000\end{array}$ & $\begin{array}{c}6100000 \\
82 \\
120000\end{array}$ & $\begin{array}{c}21738000 \\
67 \\
295000\end{array}$ \\
\hline$\%$ induced spawnings & 39 & 65 & $\mathbf{0}$ & 12 & 38 & 70 & 68 & 28 \\
\hline$\%$ natural spawnings & 61 & 35 & 100 & 88 & 62 & 30 & 32 & 72 \\
\hline$\%$ viable yolk sac larvae & 67 & 78 & 57 & 48 & 71 & 79 & 76 & 76 \\
\hline$\%$ abnormal yolk sac & 11 & 11 & 7 & 25 & 8 & 10 & 4 & 5 \\
\hline
\end{tabular}

Table 4. - Variation in fecundity (average number of eggs collected per kilogramme of female) in each tank over the period 1984-1987.

\begin{tabular}{cccc}
\hline \multirow{2}{*}{ Year } & \multicolumn{3}{c}{$\begin{array}{c}\text { Number of eggs collected } \\
\text { per kg of female in group }\end{array}$} \\
\cline { 2 - 4 } & Control & Advanced & Delayed \\
\hline $1984-1985$ & 292700 & - & 164600 \\
$1985-1986$ & 319000 & 328000 & 146000 \\
$1986-1987$ & 434600 & 502300 & 441000 \\
\hline
\end{tabular}

on the expected results still remains unexplained. As suggested by Richter et al. (1987), Devauchelle (unpubl. data), some developmental stages of oocytes might be subjected to an endogenous rhythm and are of constant duration. The conclusions concerning the role of temperature and photoperiod are very similar in most countries. In practice, however, different thermal strategies are necessary, depending on the areas considered. In Brittany, for instance, the natural temperatures range from $6-7^{\circ} \mathrm{C}$ to $17-18^{\circ} \mathrm{C}$. Thus the levels must be raised in winter (Devauchelle, 1986) to obtain spawning of D. labrax, while at other scasons eggs of this species are spawned naturally or with hormonal help and without thermal control at all. By contrast, along mediterranean and adriatic coasts or in subtropical areas, precautions are necessary mainly during summer, to keep temperatures below $24-26^{\circ} \mathrm{C}$ during the gametogenesis and between $9-22^{\circ} \mathrm{C}$ during spawning. Unfortunately, acclimation of sea bass at high temperatures has not yet allowed the modification of the conditions required for gametogenesis or spawning (Fuchs; Devauchelle, unpublished data). The worst results obtained during the delayed spawning season may be improved by more care with temperature levels. Previous works (Zanuy et al., 1986; Coves, unpublished data) related similar observations under unadapted thermal conditions during gametogenesis or thermal and photoperiodic cycle contractions. On the other hand, hatching success calculated from viable eggs depends more on incubation conditions than on the pattern of external factors to which the broodstock is subjected.
For sea bass, it must be stressed that the injection of LHRH ${ }_{a}$ on a large scale during normal or shifted spawning seasons gives as good a performance as natural spawning (these data) or as results obtained by $\mathrm{LHRH}_{a}$ on an experimental scale (Barnabé et Barnabé-Quet, 1985). Similar observations have been made on other marine fish: Chanos chanos (Lee et al., 1986), Mugil cephalus (Lee et al., 1987) or Sparus aurata (Zohar, 1986) for instance. Two major facts explain this success: firstly, the direct effect on the hypothalamo-hypophysis axis, as demonstrated by Donaldson (1986) on salmonids or Zanuy and Carillo (1987) on both marine and freshwater fish: in comparison, those of HCG which induces an immunity effect. Secondly, through prior biopsy, only those females with large oocytes (diameter over $650 \mu \mathrm{m}$ ) are selected for hormonal treatment. This avoids the forcing of immature females. The special cisors used for biopsies, already tested on flatfishes and roundfishes (Devauchelle, 1985) were frequently used (once a week) in these experiments without damage to fish or to their productivity.

In conclusion, the combined use of $\mathrm{LHRH}_{a} /$ biopsies and natural spawns, whatever the spawning season, is well suited to the large scale production of eggs. Excessive manipulation is avoided. If necessary, large batches of yolksac larvae can be produced on a chosen day. Preliminary observations did not show a significant difference in larval survival between broodstock spawning normaly and broodstock spawning out of season.

\section{CONCLUSION}

Broodstock management is not now the major problem in the development of sea bass aquaculture. Work carried out on nutrition should simplify the maintenance conditions and probably increase larval survival rates. This is of particular interest in the case of extreme rearing conditions. The high cost of temperature control could be reduced when the roles of temperature and photoperiod have been defined 
more preciscly. The use of hormones also requires further examination with regards to the developmental stage of oocytes considered for treatment. However, the results obtained enable the production of yolk sac larvae at the average price of 0.01 centime. This is a minor part of the price of 100-150 day old juvenile which is sold FF 3.50-4 (1987) along the mediterranean coast. An average of four yolk sac larvae are necessary to produce one juvenile. Finally the progress made these last 10 years on sea bass broodstock and in larval rearing make sea bass a possible candidate for further research on marine fish production, especially in the fields of genetics, nutrition, reproductive physiology, and aquaculture. This may also help to improve broodstock management and larval rearing of several other species; in particu. lar problems affecting the development of eggs of species with larvae with high growth or survival rates are now important in the development of aquaculture.

\section{Acknouledgements}

This work was made with the technical assistance of two IFREMER stations: "Aquaculture and Fisheries" at Brest; Merea, Palavas-les-Flots. Let us particularly thank J. C. Alexandre, J. F. Bouget, Y. Cladas, Y. Letty, M. Suquet.

\section{REFERENCES}

Barnabé G., 1976a. Rapport technique sur la ponte induite et lélevage des larves du loup (Dicentrarchus labrax) et de la daurade (Sparus aurata). Cons. gén. péches Méditerranée, 55, 63-116.

-, 1976b. Contribution à la connaissance de la biologie du loup (Dicentrarchus labrax L.) Poisson Serranidae. Thèse dr. État, Montpellier, $426 \mathrm{p}$.

-, 1986. L'élevage du loup et de la daurade. In : Aquaculture, 2. Technique et Documentation, Lavoisier, 627-666.

Barnabć G., R. Barnabć-Quet, 1985. Avancement et amélioration de la ponte induite chez le loup (Dicentrarchus labrax L.) à l'aide d'un analogue de LHRH injecté. Aquaculture, 49, 125-132.

Barnabé $G_{y}$ J. Paris, 1984. Ponte avancée et ponte normale du loup (Dicentrarchus labrax L.) à la station de biologie marine ct lagunaire de Sċte. In : L'aquaculture du bar et des sparidés, G. Barnabé, R. Billard Eds. INRA Publ., Paris, 1984, 63-72.

Bedier E., 1979, Production à l'échelle pilote d'alevins de loup (Dicentrarchus labrax L.) presented at The Early Life History of Fish. Symp. Woods Hole, USA, 2-5 April $1979,17 \mathrm{p}$.

Billard R., 1979. La gamétogenèse, le cycle sexuel et le contrôle de la reproduction chez les poissons Téléostéens. Bull. Fr. Pisc., 273, 117-136.

Boulincau F., 1969. Contribution à l'étude biologique du bar (Dicentrarchus labrax Linne). Thèse $3^{\circ}$ cycle, Univ. Paris-VI, $176 \mathrm{p}$.

Bromage N., C. Whitehead, J. Elliot, A. Matty, 1982. Investigations into the importance of daylenght on the photoperiodic control of reproduction in the female rainbow trout. In: Reproductice physiology of fish. C. Richter, H. Th. Goos. Eds. Pudoc Press, Wagennigen, 233-236.

Bye V. J., 1984. The role of environmental factors in the liming of reproductive cycles. In: Fish Reproduction. Strategies and Tactics. G. W. Potts, R. J. Wooton Ed., London, 187-205.

Coves D., 1985. État actuel de l’ëlevage du loup en écloserie. Aqua-Retue, 3, 26-30.
Devauchelle N., 1984. Reproduction décalée du bar (Dicentrarchus labrax) et de la daurade (Sparus aurata). In: L'Aquaculture du bar et des Sparidés. G. Barnabé, R. Billard Eds., INRA Publ., Paris, 53-62.

_, 1985. Identification du sexe et prélèvements d'ovocytes sur Turbots (Scophthalmus maximus) vivants. Bull. Fr. Pisc., 5, 293-294, 65-71.

-, 1986. Ponte en captivité et incubation de quatre poissons marins élevés en Europe. Conférence de formation MEDRAP/FAO. Production contrôlée d'alevins en Europe, Zadar/Pula (Yougoslavie, 10-28 février 1986), $50 \mathrm{p}$.

Devauchclle N., J. C. Alexandre, Y. Le Corre, Y. Letty, 1987. Spawning of sole (Solea solea) in captivity. Aquaculture, 66, 125-147.

-, 1988. Spawning of turbot (Scophehalmus maximus) in captivity. Aquaculture, 69, 159-184.

Donaldson E. M., 1986. The integrated development and application of controlled reproduction techniques in pacific salmonid aquaculture. Fish Physiol. Biochem., 2, 9-24.

Duston J., N. Bromage, in press. Photoperiodic mechanisms and thythms of reproduction in the female rainbow trout. Fish Physiol. Biochem.

Girin M., 1979. Méthodes de production des juvéniles chez trois poissons marins, le bar, la sole et le turbot. Rapp. sci. tech. CNEXO, 39, 202 p.

Girin M., N. Devauchelle, 1978. Décalage de la période de reproduction par raccourcissement des cycles photopériodiques et thermiques chez les poissons marins. Ann. Biol. Anim. Biochem. Bioghys., 18, 1059-1065.

Huet M., 1970. Traité de Pisciculture. Ch. de Wyngaert Ed., $4^{\circ}$ éd., 718 p.

Kuo C. M., C. E. Nash, Z. II. Shehaded, 1973. The grey mullet (Mugil cephalus L.) induced breeding and larval rearing research, 1972-1973. Vol. II, Ocean. Inst., Hawaï, Rep. 01.73.128.

Lam T. J., 1983. Environmental in/luences on gonadal activity in rish. In: Fish Physiology, vol IX Reproduction, Part B: Behavior and fertility controh, W. S. Hoar, D. J. Randall, E. M. Donaldson Ed., Academic Press, 65-116. 
Lee C. S., C. S. Tamaru, C. D. Kelley, J. E. Banno, 1986. Induced spawning of milkfish, chanos chanos by a single application of LHRH-analogue. Aquaculture, 58, 87-98.

Lee C. S., C. S. Tamaru, G. T. Miyamoto, C. D. Kelley, 1987. Induced spawning of grey mullet (Mugil cephalus) by LHRH. Aquaculture, 62, 327-336.

Richter C. J. J., W. J. A. R. Viveen, E. H. Eding, M. Sukkel, A. J. Rothuis, M. F. P. M. Van Hoof, F. G. J. Van Den Berg, P. G. W. J. Wan Oordt, 1987. The significance of photoperiodicity, water temperature and an inherent endogenous thythm for the production of viable eggs by the African Catfish (Clarias garupinus), kept in subtropical ponds in Israel and under israeli and dutch hatchery conditions. Aquaculture, 63, 169-185.

Shelbourne J. E., 1968. The culture of marine fish larvac, with special reference to the plaice (Pleuronectes platessa L.) and the sole (Solea solea L.). Ph. D. Thesis, Univ. London, $143 \mathrm{p}$.

Suquet M., 1986, Synthèse des donnćes sur la gestion d'un stock de reproducteurs de poissons marins (loups, daurades ainsi que charax et turbots). Rapp. st. IFREMER/Merea, Palavas-les-Flots, France, janvier 1986, 59 p.

Wooton R. J., 1982. Environmental factors in fish production. In, Reproductive physiology of fish. Proceedings of the international symposium on reproductive physiology of fish. Wageningen, The Netherlands, 2-6 August 1982, 210-219.

Zanuy S., M. Carillo, 1984. La salinité : un moyen pour retarder la ponte du bar. In: L'Aquaculture du bar et des Sparidés. G. Barnabé, R. Billard Éds., INRA Publ., Paris, 73-80.

Zanuy S., M. Carillo, F. Ruiz, 1986. Delayed gametogenesis and spawning of sea bass (Dicentrarchus labrax L.) kept under different photoperiod and temperature regincs. Fish Physiol. Biochem., 2, 53-63.

Zanuy S., M. Carillo, 1987. La reproduccion de los teleosteos y su applicacion en acuicultura. In : Reproduccion en acuicultura. J. Espinosa de los monteros, U. Labarta Eds., 1-131.

Zohar Y., R. Billard, C. Weil, 1984. La reproduction de la daurade (Sparus aurata) et du bar (Dicentrarchus labrax) : connaissance du cycle sexuel et contröle de la gamćtogenċe et de la ponte. In : L'Aquaculture du bar et des Sparidés. G. Barnabé, R. Billard Ed., INRA Publ., Paris, 3-24.

Zohar Y., 1986. Gonadotropin-releasing hormone in spawning induction in teleosts: basic and applied considerations. Symp. Tel-Aviv, Israel, franco-israélien, reproduction des poissons, 10-12 November, 1986. 